\title{
Potential Role of IGF-I in Hypoxia Tolerance Using a Rat Hypoxic-Ischemic Model: Activation of Hypoxia-Inducible Factor $1 \alpha$
}

\author{
XINGHE WANG, JIXIAN DENG, DAVID W. BOYLE, JIN ZHONG, AND WEI-HUA LEE \\ Department of Pediatrics [X.W., J.D., J.Z., W-H.L.], Department of Anatomy and Cell Biology [W-H.L.], \\ Indiana University School of Medicine, Indianapolis, Indiana, 46202, U.S.A., and The Institute of \\ Biotechnology [J.D.], Beijing 100071, China
}

\begin{tabular}{|c|c|}
\hline \multicolumn{2}{|c|}{ ABSTRACT } \\
\hline $\begin{array}{l}\text { Hypoxia preconditioning and subsequent tolerance to hy- } \\
\text { poxia-ischemia damage is a well-known phenomenon and has } \\
\text { significant implications in clinical medicine. In this investigation, } \\
\text { we tested the hypothesis that the transcriptional activation of } \\
\text { IGF-I is one of the underlying mechanisms for hypoxia-induced } \\
\text { neuroprotection. In a rodent model of hypoxia-ischemia, hypoxia } \\
\text { preconditioning improved neuronal survival as demonstrated by } \\
\text { decreased hypoxia-ischemia-induced neuronal apoptosis. To } \\
\text { study the role of IGF-I in hypoxia tolerance, we used in situ } \\
\text { hybridization to examine IGF-I mRNA distribution on adjacent } \\
\text { tissue sections. In cerebral cortex and hippocampus, hypoxia } \\
\text { preconditioning resulted in an increase in neuronal IGF-I mRNA } \\
\text { levels with or without hypoxia-ischemia. To test its direct effects, } \\
\text { we added IGF-I to primary neuronal culture under varying } \\
\text { oxygen concentrations. As oxygen concentration decreased, neu- } \\
\text { ronal survival also decreased, which could be reversed by IGF-I, } \\
\text { especially at the lowest oxygen concentration. Interestingly, } \\
\text { IGF-I treatment resulted in an activation of hypoxia-inducible } \\
\text { factor } 1 \alpha \text { (HIF- } \alpha \text { ), a master transcription factor for hypoxia- } \\
\text { induced metabolic adaptation. To evaluate whether IGF-I tran- } \\
\text { scriptional activation correlates with HIF-1 } \alpha \text { activity, we studied } \\
\text { the time course of HIF- } \alpha \text { DNA binding activity in the same rat } \\
\text { model of hypoxia-ischemia. After hypoxia-ischemia, there was } \\
\text { an increase in HIF-1 } \alpha \text { DNA binding activity in cortical tissues, }\end{array}$ & $\begin{array}{l}\text { with the highest increase around } 24 \mathrm{~h} \text {. Like IGF-I mRNA levels, } \\
\text { hypoxia preconditioning increased HIF-1 } \alpha \text { DNA binding activity } \\
\text { alone or with subsequent hypoxia ischemia. Overall, our results } \\
\text { suggest that IGF-I transcriptional activation is one of the meta- } \\
\text { bolic adaptive responses to hypoxia, which is likely mediated by } \\
\text { a direct activation of HIF-1 } \alpha \text {. (Pediatr Res 55: 385-394, 2004) } \\
\qquad \text { Abbreviations } \\
\text { HIF-1, hypoxia-inducible factor } 1 \\
\text { HIF-1 } \alpha \text {, hypoxia-inducible factor } 1 \alpha \\
\text { HIF-1 } \beta \text {, hypoxia-inducible factor } 1 \beta \\
\text { VEGF, vascular endothelial growth factor } \\
\text { dNTP, nucleotides } \\
\text { dGTP, 2'-deoxyguanosine 5'-triphosphate, sodium salt } \\
\text { dCTP, 2'-deoxycytidine 5'-triphosphate, sodium salt } \\
\text { dTTP, 2'-deoxythymidine 5'-triphosphate, sodium salt } \\
\text { dATP, 2'-deoxyadenosine 5'-triphosphate, sodium salt } \\
\text { SSC, sodium chloride and sodium citrate buffer } \\
\text { EMSA, electrophoretic mobility shift assay } \\
\text { W18, wild-type } \\
\text { M18, mutant } \\
\text { MTT, 3-(4,5-dimethylthiazol-2-yl)-2,5-diphenyl- } \\
\text { tetrazoliumbromide }{ }^{+++} \text {] } \\
\text { RT-PCR, reverse transcription PCR }\end{array}$ \\
\hline
\end{tabular}

Hypoxia preconditioning is a process by which prior treatment of a sublethal dose of hypoxia renders cells tolerant to otherwise lethal hypoxia or hypoxia/ischemia insult. This phenomenon has been observed at cellular (1), tissue (2), and whole animal levels (3-6). Preconditioning and subsequent tolerance is not unique to hypoxia. In the brain, neurons can become tolerant to ischemia if exposed to a brief sublethal

Received April 1, 2003; accepted September 3, 2003.

Correspondence: Wei-Hua Lee, M.D., Riley Research, Rm. 208, 699 West Dr., Indiana University Medical Center, Indianapolis, IN 46202, U.S.A.; e-mail: whlee@iupui.edu

Supported by The National Institute of Neurologic Diseases and Stroke and the Riley Memorial Association.

DOI: 10.1203/01.PDR.0000111482.43827.40 episode of ischemia $(7,8)$, spreading depression $(9)$, or exposure to metabolic inhibitors (10). To survive, cells seem to be armed with sophisticated adaptive mechanisms that enable them to sense the nutritional deficiency in the environment and make subsequent metabolic adjustments. Understanding these mechanisms will help us gain insights into the cells' adaptive responses to metabolic deficiencies.

IGF-I is a pleiotropic anabolic growth factor essential for the development of the CNS. One salient function of IGF-I is to promote neuronal survival during development as well as neuronal injury. This has been demonstrated in a rodent model of hypoxia-ischemia encephalopathy (11-17). Soon after the hypoxia-ischemia insult, there is a rapid decrease in neuronal 
IGF-I mRNA levels (18), and the decrease is inversely correlated with the length of hypoxia duration (19). If exogenous IGF-I is supplemented through intraventricular infusion, this hypoxia-ischemia-induced neuronal damage can be alleviated $(15,20)$. Because hypoxia preconditioning can protect neurons from subsequent hypoxia-ischemic insult (4), we want to know whether IGF-I is involved in the metabolic adaptation that was induced by hypoxia preconditioning.

One established mechanism underlying cells' hypoxia responses involves a heterodimeric transcription factor, HIF-1, which consists of two subunits, HIF- $1 \alpha$ and HIF-1 $\beta$ (21). Both subunits belong to a family of basic helix-loop-helix transcription factors and are required for DNA binding and transactivation of target genes (22). Although both are constitutively expressed, only HIF-1 $\alpha$ levels in the cytoplasm are regulated by oxygen tension (23). HIF-1 $\alpha$ activity is regulated by oxygen concentration via interacting with a family of iron-dependent prolyl hydroxylase (24) and asparaginyl hydroxylase (25). During normoxia, HIF- $1 \alpha$ is rapidly degraded by the ubiquitinproteosome pathway $(26,27)$. Soon after oxygen tension decreases, HIF- $1 \alpha$ is stabilized and quickly accumulates in the nucleus (28), where it transactivates adaptive genes, such as glucose transporter 1, VEGF, and erythropoietin (23). The stabilization of HIF- $1 \alpha$ may contribute to metabolic adaptations and subsequent hypoxic tolerance $(6,29)$.

In human Hep-G2 (hepatocellular liver carcinoma cell line) hepatoma cells, both IGF-I and insulin increased HIF-1 $\alpha /$ aryl hydrocarbon receptor nuclear translocator DNA binding activity and the transcription of target genes in a dose-dependent manner (30). In the same cell line, hypoxia stimulated the transcription of IGF binding protein 1 , one of the HIF- $1 \alpha$ target genes (31). On the other hand, intraventricular and systemic IGF-I infusion induced an increase in HIF- $1 \alpha$ levels, suggesting a potential link between IGF-I and the HIF- $1 \alpha$ pathway (32). To date, whether IGF-I's neuroprotection involves the HIF-1 pathway against hypoxia-ischemia-induced neuronal injury has not been investigated. In the current study, we tested the hypothesis that IGF-I promotes neuronal survival in hypoxia tolerance to hypoxic-ischemic injury partially by activating HIF- $1 \alpha$. To accomplish this, we used a hypoxia-ischemia model on immature rat brains with or without hypoxia preconditioning. The associations were sorted among the number of apoptotic neurons, HIF- $1 \alpha$ DNA binding activity, and IGF-I mRNA levels in vivo and in vitro.

\section{MATERIALS AND METHODS}

Perinatal hypoxia-ischemia model. All animal studies were approved by Indiana University Animal Review Board. Pregnant Sprague-Dawley rats (Charles River Breeding Laboratories, Portage, MI, U.S.A.) were housed in individual cages and fed standard laboratory chow ad libitum. Hypoxia-ischemia was induced in 7-d-old rat pups as previously described (33) with minor modifications. Briefly, 7-d-old pups (13-19 g of body weight) were anesthetized with a mixture of halothane (4\% for induction, $1-1.5 \%$ for maintenance) and $30 \%$ oxygen. The left common carotid artery of each pup was exposed, isolated from nerve and vein, and ligated with 3-0 surgical silk. The wound was sutured, and the rat pups were returned to their mothers for $3 \mathrm{~h}$ to allow recovery. Sham-operated animals underwent the same operative procedure except that the exposed carotid artery was not ligated (hypoxia only). Thereafter, two to three pups were placed in $500-\mathrm{mL}$ airtight jars and exposed to a humidified nitrogen-oxygen mixture ( $8 \%$ oxygen) delivered at $5-6 \mathrm{~L} / \mathrm{min}$. During the $150-\mathrm{min}$ hypoxia, the jars were partially submerged in a $37^{\circ} \mathrm{C}$ water bath to maintain a constant thermal environment. Brains were then collected at designated time points after termination of hypoxia, immediately frozen on dry ice, and stored at $-70^{\circ} \mathrm{C}$ until analyzed. For hypoxia preconditioning, pups (P6) were first placed in the $37^{\circ} \mathrm{C}$ water bath for $20 \mathrm{~min}$ followed by $2.5 \mathrm{~h}$ of hypoxic exposure $\left(8 \% \mathrm{O}_{2} / 92 \% \mathrm{~N}_{2}\right)$, then returned to their dam. Twentyfour hours later, hypoxia-ischemia treatment was given as described above. All rat pups were then returned to their dams for $1,3,5,24$, or $72 \mathrm{~h}$, after which they were killed by decapitation and the brains were removed and frozen in isopentane at $-40^{\circ} \mathrm{C}$ and stored at $-70^{\circ} \mathrm{C}$ until analyzed. Usually, the combined hypoxia and ischemia produces brain damage predominantly in the territory of the middle cerebral artery of the cerebral hemisphere ipsilateral to the carotid artery occlusion (33). Damage does not usually occur in the contralateral cerebral hemisphere or in either hemisphere when the animal is exposed to arterial ligation or hypoxia alone.

Primary cortical neuronal culture. The cortices were collected from newborn rat pups and minced. An aliquot of ice-cold PBS was added into the minced tissues, which were then centrifuged at $1000 \mathrm{rpm}$ at $4^{\circ} \mathrm{C}$ and the supernatants were discarded. An aliquot of $0.25 \%$ trypsin was added and incubated at $37^{\circ} \mathrm{C}$ for 15 min to produce a single cell suspension (shaken once every $5 \mathrm{~min}$ ). The precipitates were discarded and the supernatants were centrifuged again at $1000 \mathrm{rpm}$ at $4{ }^{\circ} \mathrm{C}$ for $5 \mathrm{~min}$. The cell pellets were diluted to appropriate concentration with Neurobasal in 2\% B27 (Invitrogen, Carlsbad, CA, U.S.A.) and were plated into poly-D-lysine-coated dishes (BD Biosciences, Franklin Lakes, NJ, U.S.A.). Usually, the cells were used at 4-6 d after plating. Before each treatment, cells were rinsed and then incubated in serum-free Dulbecco's modified Eagle's medium with high glucose (Invitrogen). All experiments were conducted under serum-free conditions.

Klenow staining for apoptotic cells. Having both 5'-3' DNA polymerase and 3'-5' exonuclease activity, Klenow has more substrates and, therefore, is more sensitive than the commonly used terminal transferase method. Briefly, brains were obtained from animals at $24 \mathrm{~h}$ of recovery from $150 \mathrm{~min}$ of hypoxia and unilateral hypoxia-ischemia. Fresh frozen sections $(16 \mu \mathrm{m})$ were fixed in $4 \%$ paraformaldehyde for $30 \mathrm{~min}$ and rinsed in PBS before being treated with $2 \% \mathrm{H}_{2} \mathrm{O}_{2}$ for $15 \mathrm{~min}$ at room temperature. After quick rinses in PBS, sections were first incubated with the Klenow fragment (40 unit $/ \mathrm{mL}$, Invitrogen) in reaction buffer without dNTP for $10 \mathrm{~min}$ at room temp. Then, slides were transferred into new Klenow (40 unit) in fresh reaction buffer containing dGTP, dCTP, dTTP, and biotinylated dATP $\left(10 \mu \mathrm{M}\right.$ each) and incubated at $37^{\circ} \mathrm{C}$ for $1 \mathrm{~h}$. The reaction was terminated in SSC at $75^{\circ} \mathrm{C}$ for $10 \mathrm{~min}$ and rinsed in PBS. Then, sections were incubated with avidin biotin complex (1-300 dilution, Vector Laboratories, Burlingame, 
CA, U.S.A.) in PBS for $1 \mathrm{~h}$ at room temperature. The color reaction was developed by incubating tissue sections with 3,3' diaminobenzidine tetrahydrochloride $(0.5 \mathrm{mg} / \mathrm{mL})$ diluted in $\mathrm{H}_{2} \mathrm{O}$. For control sections, either Klenow or the avidin biotin complex was omitted from the procedure. No color reaction was detected.

\section{EMSA}

EMSA was performed on nuclear extracts from cultured cortical neurons and cortical tissues using a ${ }^{32} \mathrm{P}$-labeled oligonucleotide containing a wild-type (W18) or mutant (M18) HIF-1 binding site (21). The sense strand sequences of the double-stranded W18 and M18 oligonucleotides are 5'GCCCTACGTGCTGTCTCA-3' and 5'-GCCCTAAAAGCTGTCTCA-3', respectively. Briefly, cultured cortical neurons were lightly trypsinized, pelleted, and resuspended in cold PBS. The small pieces of brain tissue $(\sim 200 \mathrm{mg})$ were washed three times with cold PBS and were homogenized with a type-A Dounce homogenizer pestle (six strokes). The homogenates were centrifuged and the supernatants were removed. The cell or tissue pellets were suspended in 5 volumes of buffer A (10 mM HEPES, $\mathrm{pH} 7.9,1.5 \mathrm{mM} \mathrm{MgCl}_{2}, 10 \mathrm{mM} \mathrm{KCl}, 0.5$ $\mathrm{mM}$ DTT, and $0.5 \mathrm{mM}$ phenylmethylsulforyl fluoride $1 \mathrm{mM}$ ) and centrifuged at $2500 \times g$ for $5 \mathrm{~min}$ at $4^{\circ} \mathrm{C}$. Pellets were resuspended in 2 volumes of buffer A and lysed by pipette up and down. The lysates were kept on ice for $10 \mathrm{~min}$ and nuclei were pelleted at $10,000 \times g$ for $10 \mathrm{~min}$. Then, pellets were resuspended in 1.5 volumes of buffer $\mathrm{C}(420 \mathrm{mM} \mathrm{KCl}, 20 \mathrm{mM}$ HEPES pH 7.9, $1.5 \mathrm{mM} \mathrm{MgCl}, 0.5 \mathrm{mM}$ phenylmethylsulforyl fluoride, $0.5 \mathrm{mM}$ DTT, and $0.2 \mathrm{mM}$ EDTA) and incubated for 15 min with gentle agitation at $4{ }^{\circ} \mathrm{C}$. The nuclear extracts were centrifuged at $15,000 \times g$ for $30 \mathrm{~min}$, and the protein concentrations in the supernatants were measured by a Bio-Rad protein assay (Bio-Rad, Hercules, CA, U.S.A.), following manufacturer instructions. Binding reactions were performed at $4^{\circ} \mathrm{C}$ for $15 \mathrm{~min}$ using $10 \mu \mathrm{g}$ of nuclear protein and $1 \mu \mathrm{L}$ $(50,000 \mathrm{cpm})$ of labeled oligonucleotide in $20 \mu \mathrm{L}$ of binding buffer (10 mM HEPES pH 7.9, $60 \mathrm{mM} \mathrm{KCl,} 1 \mathrm{mM} \mathrm{MgCl}_{2}, 0.2$ mM EDTA, 5 mM DTT, 7\% glycerol, poly dI-dC $1.5 \mu \mathrm{g}$ ). DNA-protein complexes were separated from the unbound probe on native $5 \%$ polyacrylamide gels at $180 \mathrm{~V}$ for $2.5 \mathrm{~h}$. The gels were vacuum dried and exposed to Kodak film for $8-15 \mathrm{~h}$ at $-80^{\circ} \mathrm{C}$. Visual inspection of the free probe bands at the bottom of the gels confirmed that equivalent amounts of radiolabel probe were used for each sample. Super shifts were performed by incubating a HIF-1 $\alpha$ antibody (1-200 dilution; $\mathrm{BD}$ Biosciences) with the binding mixture for $12 \mathrm{~h}$ before adding the radiolabeled HIF-1 probe. The reaction mixture was incubated for $20 \mathrm{~min}$, and the complexes were resolved as described above.

\section{RT-PCR}

Total RNA was prepared by an RNAzol method according to manufacturer's instructions. A $20-\mu \mathrm{L}$ RT reaction system contained $1 \mu \mathrm{L}$ of sample ( $1 \mu \mathrm{g}$ of total RNA), $1 \mu \mathrm{L}$ polydT, $9 \mu \mathrm{L}$ diethyl pyrocarbonate water, $4 \mu \mathrm{L} 5 \times$ synthesis buffer, 1 $\mu \mathrm{L} 10 \mathrm{mM}$ dNTP, $2 \mu \mathrm{L} 0.1 \mathrm{M}$ DTT, $1 \mu \mathrm{L}$ reverse transcriptase
SuperscriptII (Invitrogen), and $1 \mu \mathrm{L}$ RNase inhibitor. Primer sequences are as follows:

IGF-I

Forward primer: 5'-3': GCCACAGCCGGACCA GAG Reverse primer: 5'-3': GATTCTGTAGGTCTTGTT TCC

Glucose transporter 1

Forward primer: 5'-3': CATCGCCCTGGCCCTGCAGGAGC Reverse primer: 5'-3': GGCACCCCCCTGCCGGAAGCCGGA

Histone 3.3

Forward primer: 5'-3': GCAAGAGTGCGCCCTCTACTG Reverse primer: 5'-3': GGCCTCACTTGCCTCCTGCAA

The reaction was carried out at $42^{\circ} \mathrm{C}$ for $50 \mathrm{~min}$; then, $70^{\circ} \mathrm{C}$ for $10 \mathrm{~min}$ to denature reverse transcriptase. A $25 \mu \mathrm{L}$ PCR reaction mixture contained 1 unit DNA polymerase Tfl (Invitrogen), $2.5 \mu \mathrm{L} 10 \times$ synthesis buffer, $2.0 \mu \mathrm{L} 25 \mathrm{mM}$ $\mathrm{MgSO}_{4}, 0.5 \mu \mathrm{L}$ dNTP, $1.0 \mu \mathrm{L}$ primer, respectively, $2.5 \mu \mathrm{L}$ RT product, and diethyl pyrocarbonate water. Denature temperature was set at $94^{\circ} \mathrm{C}$, annealing temperature $59^{\circ} \mathrm{C}$, and extending temperature $72^{\circ} \mathrm{C}$. Cycle was 28. DNA products were quantified after PAGE.

\section{IN SITU HYBRIDIZATION}

In situ hybridization histochemistry was used to examine the transcription of the endogenous IGF-I gene. The rat IGF-I cDNA clone used for the synthesis of cRNA probes has been described in detail previously (34). cRNA probes were synthesized in $10 \mu \mathrm{L}$ reaction mixture containing $100 \mu \mathrm{Ci}$ each ${ }^{35} \mathrm{~S}-\mathrm{CTP}$ and ${ }^{35} \mathrm{~S}$-UTP (Amersham Pharmacia Biotech, Piscataway, NJ, U.S.A.), $10 \mathrm{mM} \mathrm{NaCl}, 6 \mathrm{mM} \mathrm{MgCl} 2,40 \mathrm{mM}$ Tris (pH 7.5), $2 \mathrm{mM}$ spermidine, $10 \mathrm{mM}$ DTT, $500 \mu \mathrm{M}$ each unlabeled ATP and GTP, $25 \mu \mathrm{M}$ each unlabeled UTP and CTP, $1 \mu \mathrm{g}$ linearized template, 15 units of the appropriate polymerase (BRL), and 15 units RNasin (Promega, Madison, WI, U.S.A.). The reaction was incubated at $42^{\circ} \mathrm{C}$ for $60 \mathrm{~min}$, after which the DNA template was removed by digestion with DNase I. Average specific activity of probes generated by this protocol was $2-3 \times 10^{8} \mathrm{dpm} / \mu \mathrm{L}$.

Before hybridization, tissue sections were warmed to $25^{\circ} \mathrm{C}$, fixed in $4 \%$ formaldehyde, and acetylated in $0.25 \%$ acetic anhydride $/ 0.1 \mathrm{M}$ triethanolamine hydrochloride $/ 0.9 \% \mathrm{NaCl}$. Tissues were dehydrated through an ethanol gradient, delipidated in chloroform, rehydrated, and air-dried. ${ }^{35} \mathrm{~S}$-labeled cRNA probes were added to a fresh hybridization buffer $\left(10^{7}\right.$ $\mathrm{cpm} / \mathrm{mL}$ ), which was composed of $50 \%$ formamide, $0.3 \mathrm{M}$ $\mathrm{NaCl}, 20 \mathrm{mM}$ Tris $\mathrm{HCl}$ (pH 8), $5 \mathrm{mM}$ EDTA, $50 \mu \mathrm{g}$ tRNA/mL, $10 \%$ dextran sulfate, $10 \mathrm{mM}$ DTT, and $0.02 \%$ each of BSA, Ficoll, and polyvinylpyrrolidone. The hybridization buffer was added to sections, which were then covered with glass coverslips and placed in humidified chambers overnight (14 h) at $55^{\circ} \mathrm{C}$. Slides were then washed several times in $4 \times \mathrm{SSC}$ to remove coverslips and hybridization buffer; then they were dehydrated and immersed in $0.3 \mathrm{M} \mathrm{NaCl}, 50 \%$ formamide, 20 $\mathrm{mM}$ Tris $\mathrm{HCl}$, and $1 \mathrm{mM}$ EDTA at $60^{\circ} \mathrm{C}$ for $15 \mathrm{~min}$. Next, sections were treated with RNase A $(20 \mu \mathrm{g} / \mathrm{mL}$, Roche Molecular Biochemicals, Indianapolis, IN, U.S.A.) for $30 \mathrm{~min}$ at 
$37^{\circ} \mathrm{C}$, and then passed through graded salt solutions, followed by a $15 \mathrm{~min}$ wash in $0.1 \times \mathrm{SSC}$ at $50^{\circ} \mathrm{C}$. The slides were dehydrated and air-dried and apposed to Hyperfilm-beta Max (Amersham Pharmacia Biotech) for 2-5 d and then dipped in Kodak NTB2 nuclear emulsion, stored with desiccant at $4^{\circ} \mathrm{C}$ for $6-15 \mathrm{~d}$, developed, and stained with cresyl violet or hematoxylin and eosin for microscopic evaluation.

\section{MTT ASSAY}

Cell proliferation and viability assays were done in accordance with the protocol provided by R \& D Systems (Minneapolis, MN, U.S.A.). Briefly, cortical neurons from newborn rats were cultured in flat-bottomed, poly-D-lysine-coated, 96well tissue culture plates (BioCoat, BD Biosciences). After each treatment, MTT was added to the wells and the cells were incubated at $37^{\circ} \mathrm{C}$ for $2.5 \mathrm{~h}$. MTT was reduced by metabolically active cells to insoluble purple formazan dye crystals. Detergent was then added to the wells, and cells were incubated for $3 \mathrm{~h}$ at $37^{\circ} \mathrm{C}$ in the dark. The dye crystals were dissolved in the detergent, and the absorption was read by a plate reader at $570 \mathrm{~nm}$ with a reference wavelength of $650 \mathrm{~nm}$.

\section{STATISTICAL ANALYSIS}

To count apoptotic cells, areas of analysis were selected from the cortices, hippocampi (CA1 to CA3) and thalami. For each treatment, three areas of each cortex, hippocampus, and thalamus were photographed and counted for apoptotic cells per animal, resulting in 12 areas of cortex, hippocampus, and thalamus, respectively (four animals per treatment). The extent of apoptosis was evaluated in the hemisphere ipsilateral and contralateral to the carotid artery ligation, with or without preconditioning. ANOVA was used to test the difference in the numbers of apoptotic cells with each treatment. The differences between means of OD measurements from film autoradiograph were tested by the Student $t$ test.

\section{RESULTS}

Rat model of hypoxia-ischemia. During 150 min of hypoxia, most animals $(98 \%)$ that had unilateral carotid artery ligation (98\%) showed behavioral disturbances including seizure (45\%), involuntary limb movements, and alteration in consciousness. Gross inspections of the brain specimens at $3 \mathrm{~d}$ after hypoxia-ischemia showed brain edema, softening, and necrosis in the hemisphere ipsilateral to carotid artery ligation.

Apoptotic cell death after hypoxia and hypoxia-ischemia. At postnatal d 7, whereas hypoxia alone resulted in very few apoptotic cells, hypoxia-ischemia produced substantial apoptotic cell death. As shown in Figure 1, Klenow staining detected many cells undergoing apoptotic cell death in the hippocampal pyramidal cell layer (CA1, Fig. $1 B$ ) and in the cortices (Fig. $1 D$ ) obtained from hemispheres that had hypoxia-ischemia. The Klenow staining in these cells showed a distinct nuclear pattern, which is consistent with apoptotic morphology (Fig. 2). The numbers of apoptotic cells were more abundant in the
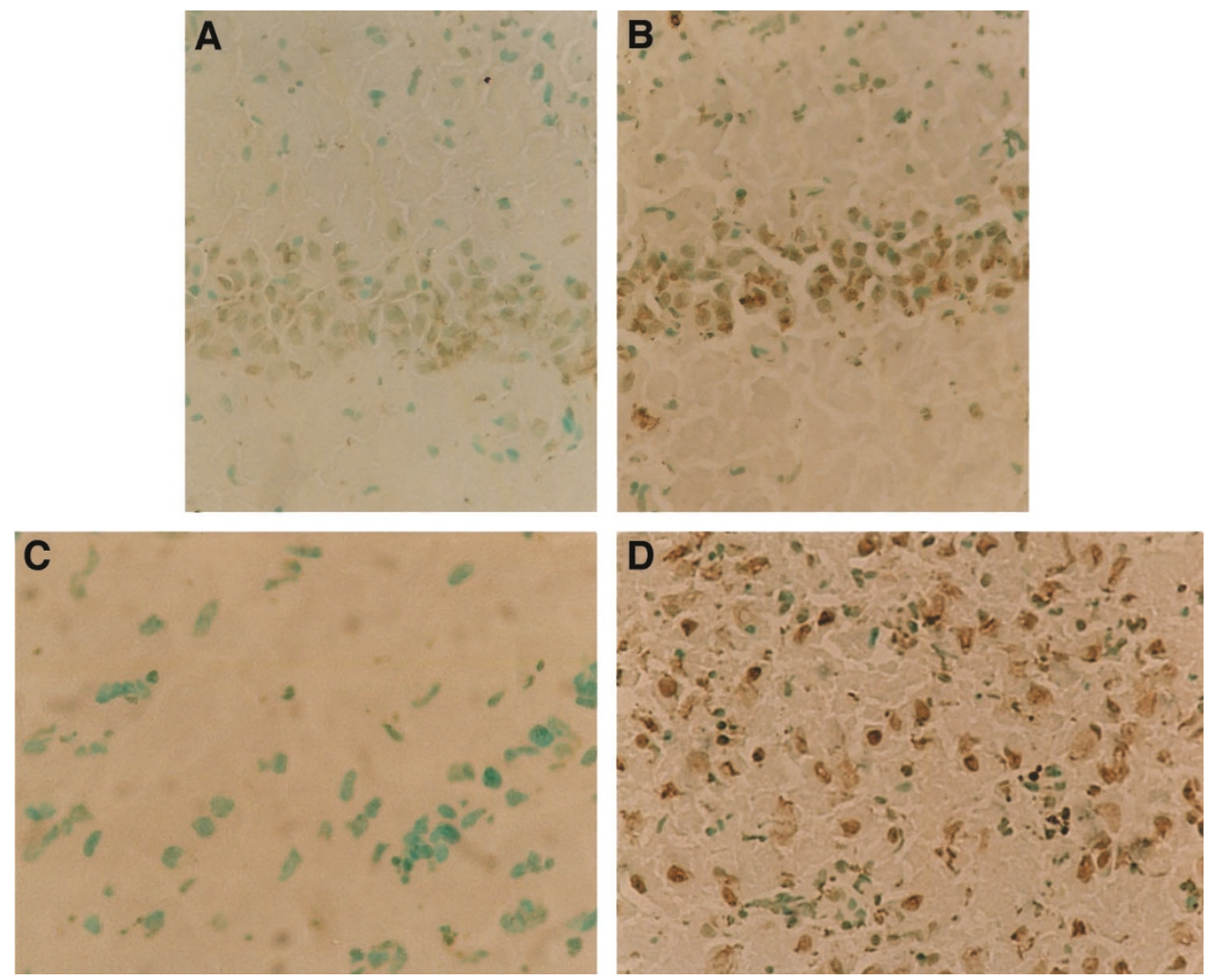

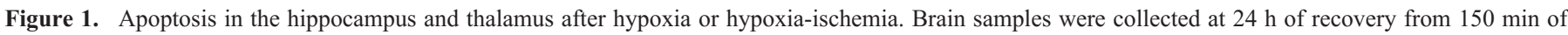

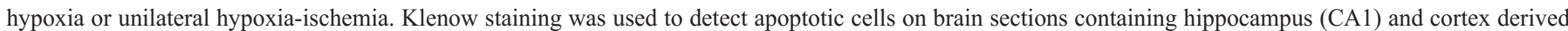

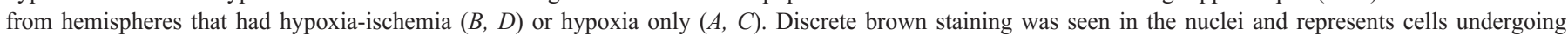
apoptosis. In both brain regions, apoptotic cells were more abundant in the hemisphere that had hypoxia-ischemia than in the one that had hypoxia only. 

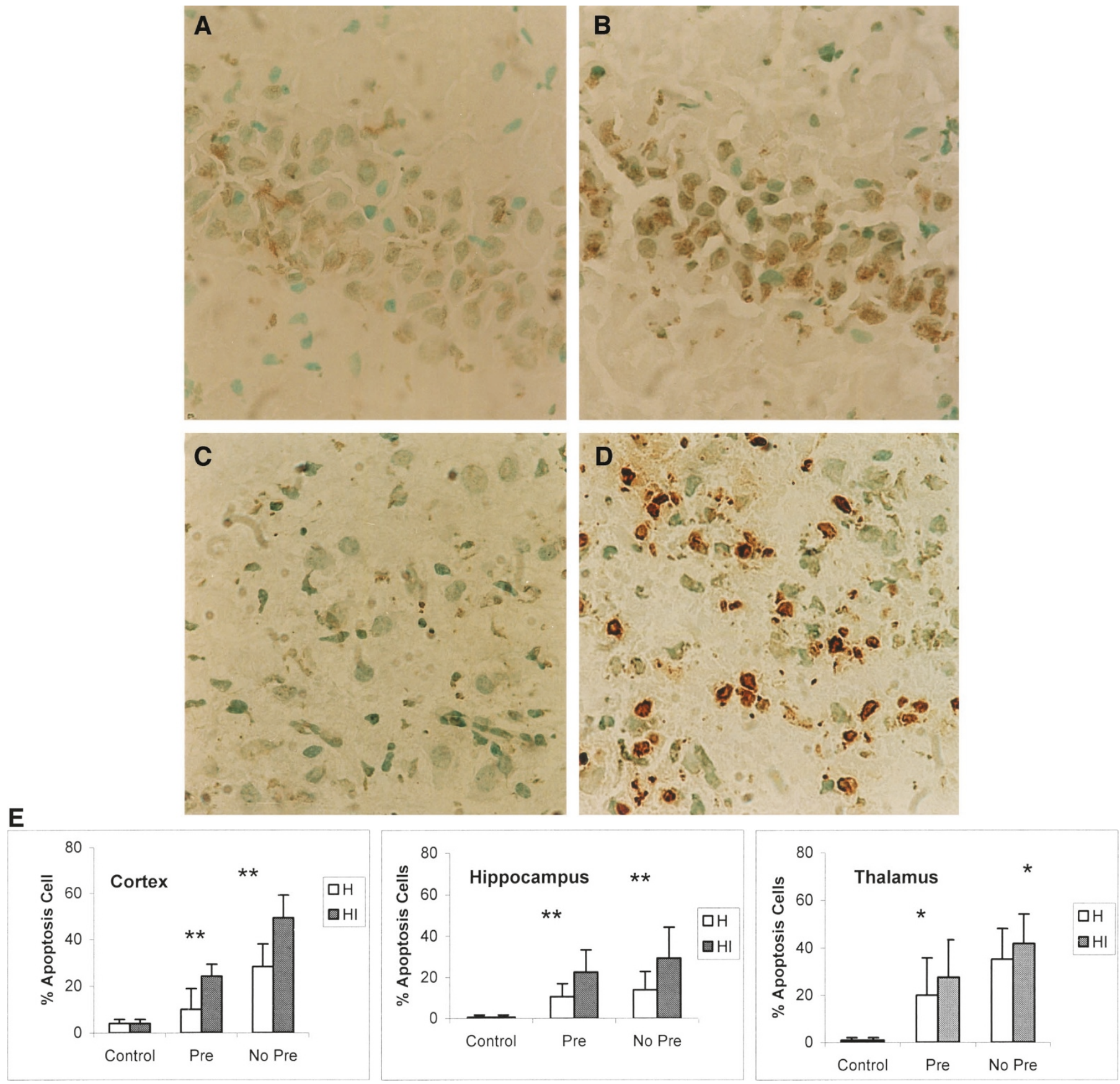

Figure 2. Hypoxia preconditioning improved neuronal survival. (a) Klenow staining was used to detect apoptotic cells after hypoxia-ischemia insult with ( $A$, $C$ ) or without $(B, D)$ hypoxia preconditioning, by which animals were treated with 150 min hypoxia. After 24 h of recovery, animals were submitted to hypoxia again or hypoxia-ischemia. Representative regions of hippocampus (CA1) $(A, B)$ and thalamus $(C, D)$ are shown below. In both brain regions, more neurons (recognized by morphology) showed positive nuclear Klenow staining in the hemisphere without hypoxia preconditioning. (b) In three brain areas that are known to be sensitive to hypoxic-ischemic injury, three microscopic fields were selected from three anatomically matched sections that were taken from each of four animals. Within each field, the number of total cells and Klenow staining positive cells were counted and expressed as percentage of apoptotic cells. The results are expressed as mean percentage of apoptotic cells in total counted cells \pm SD. The differences in the mean percentage of apoptotic cells were analyzed by ANOVA. $* p<0.05$ between mean percentage of apoptotic cells in regions that had hypoxia preconditioning and those that had no preconditioning. **In addition to above $(*), p<0.05$ between mean percentage of apoptotic cells in hemispheres that had hypoxia and the ones that had hypoxia-ischemia.

thalamus, cortex, and hippocampus than in other brain regions. Within each of the three regions, there were differences in the density of apoptotic cells in different areas (Fig. 2A). For example, more apoptotic cells were detected in the CA1 region than in CA3, dentate gyrus, and CA2, in a descending order. Based on the morphology and location, cells containing positive Klenow staining were likely to be neurons.
Hypoxia preconditioning improved neuronal survival in hemispheres that had either hypoxia alone or hypoxiaischemia (Fig. 2, $A$ and $B$ ). In all three brain regions, neuronal survival was significantly improved with $150 \mathrm{~min}$ preconditioning at $24 \mathrm{~h}$ before hypoxia or hypoxia-ischemia insult (Fig. 2B). With hypoxia preconditioning, there were fewer cells stained positive by Klenow staining and more 
morphologic organizations in each region, as shown in Figure $2 A$.

Increased IGF-I gene expression after hypoxia preconditioning. To test whether IGF-I is involved in the hypoxia tolerance, we applied in situ hybridization histochemistry to the tissue sections derived from animals that had hypoxia or hypoxia-ischemia, with or without preconditioning (Fig. $3 A$ ).

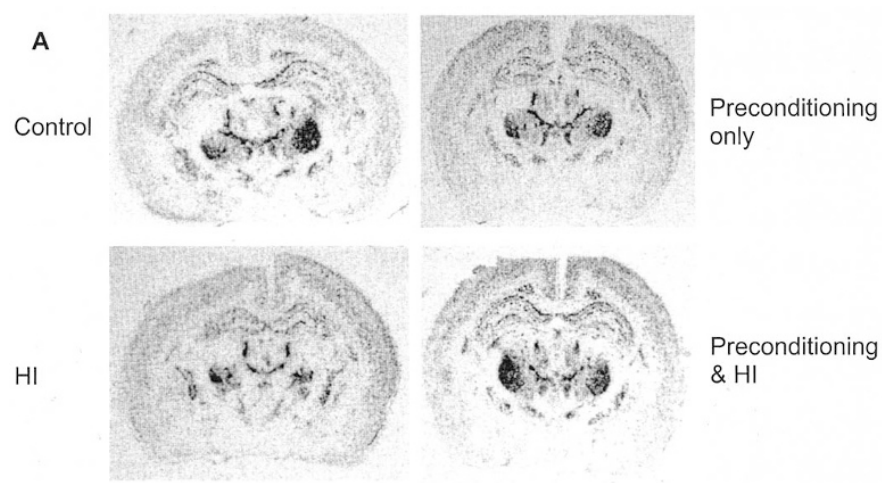

B
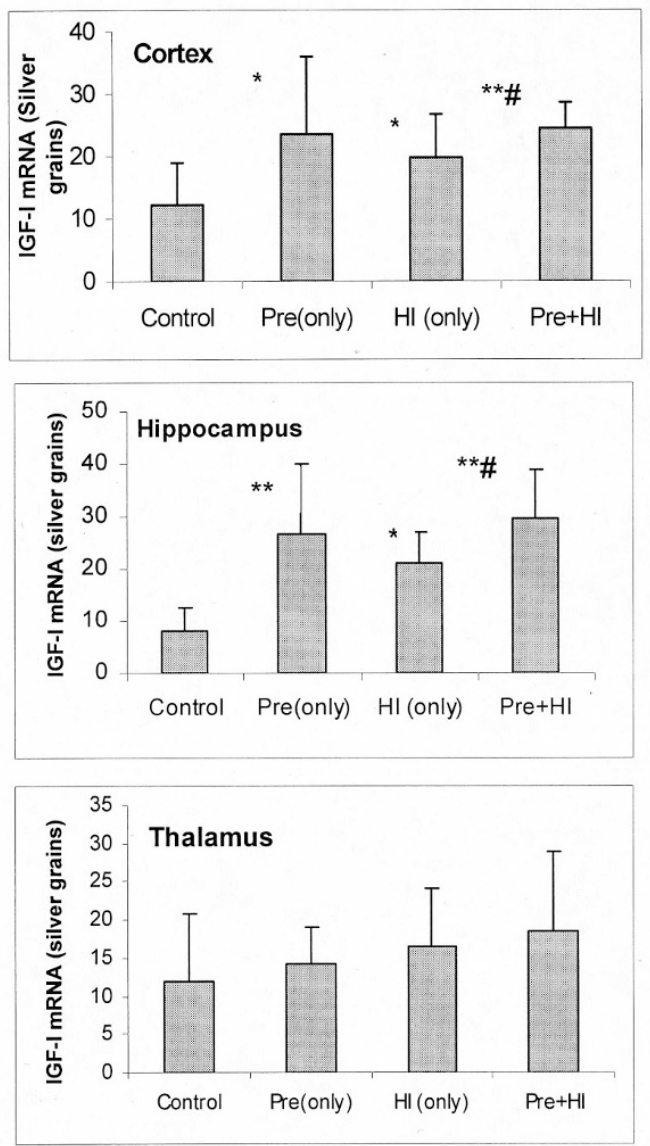

Figure 3. Distribution of IGF-I mRNA after hypoxia-ischemia $(H I)$ with or without hypoxia preconditioning. At $24 \mathrm{~h}$ of recovery, the distribution of IGF-I mRNA was examined by in situ hybridization histochemistry using a specific cRNA probe. One section from each of four to six brains per experimental group was used in a single in situ hybridization experiment. Results were evaluated by film autoradiograph and representative film images are shown $(A)$. IGF-I mRNA levels were measured by the number of silver grains in cortical neurons in areas that are supplied by middle cerebral artery. The bar graph $(B)$ shows the mean $( \pm \mathrm{SD})$ value of silver grains per neuron. ${ }^{*} p<0.05$ and $* * p<0.005$ between mean values between control group and experimental group. $\# p<0.05$ between $\mathrm{HI}$ only and $\mathrm{HI}+$ hypoxia preconditioning.

The distribution of IGF-I mRNA was consistent with previous reports, with high levels of IGF-I mRNA in large relay neurons of somatosensory and cerebellar nuclei (34). Afer hypoxia or hypoxia-ischemia, the increase in IGF-I mRNA was mainly observed in the cerebral cortex and hippocampus (Fig. 3B). The levels of IGF-I mRNA were quantified by counting silver grains in neurons in tissue sections that were treated with photographic emulsion. Compared with those without hypoxia preconditioning, there was a significant increase in neuronal IGF-I mRNA in the hypoxic-ischemic hemispheres that had hypoxia preconditioning (Fig. 3B). These results were consistent with the changes seen in IGF-I mRNA levels in cortical tissues measured by RT-PCR (Fig. 4). Hypoxia preconditioning alone resulted in an increase in IGF-I mRNA levels in cortical tissues. More importantly, hypoxia preconditioning
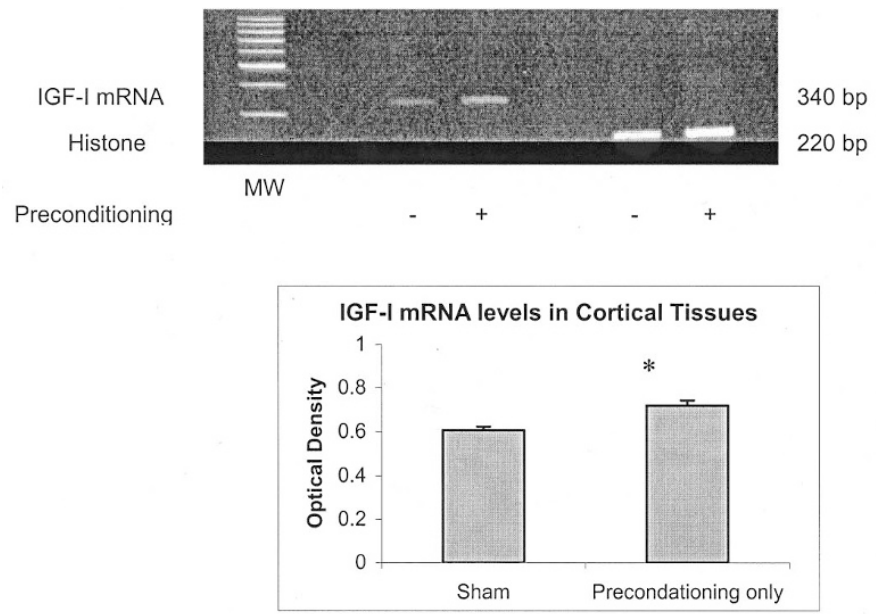

\section{IGF-I mRNA \\ Histone} Sham

Preconditioning Hypoxia-ischemia

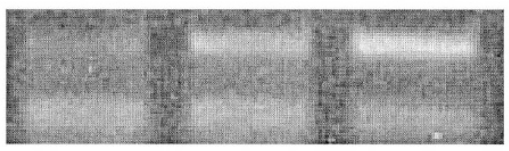

$340 \mathrm{bp}$ $220 \mathrm{bp}$

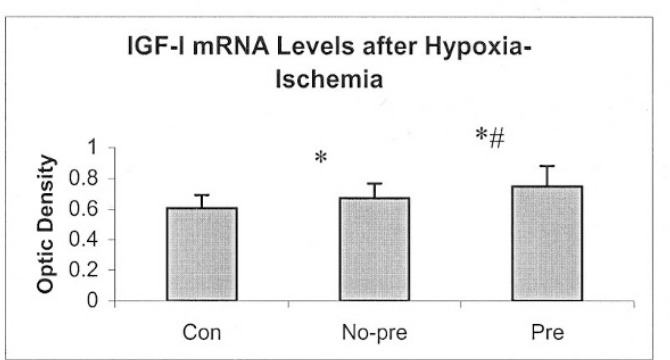

Figure 4. IGF-I mRNA increases after hypoxia preconditioning. At $24 \mathrm{~h}$ of recovery, tissue samples were obtained from cortex that were supplied by middle cerebral artery. IGF-I mRNA levels were measured in sham control, hypoxia $(n=4$, top), and hypoxia-ischemia with and without hypoxia preconditioning ( $n=6$, middle) using RT-PCR analysis. The levels of IGF-I mRNA were estimated by densitometry measurement. ${ }^{*} p<0.05$ compared with the mean value of IGF-I mRNA levels in sham-operated cortical tissue. $\# p<0.05$ compared with the mean value of IGF-I mRNA levels in cortical tissue from hemisphere that had hypoxia-ischemia without preconditioning. 
preceding hypoxia-ischemia resulted in higher IGF-I mRNA levels in cortical tissue than was seen without the preconditioning (Fig. 4). These results suggest that hypoxia preconditioning activates IGF-I gene transcription, which may contribute to the hypoxia tolerance.

IGF-I activated HIF-1 $\alpha$ and promoted the survival of cultured cortical neurons. To investigate potential cellular mechanisms of IGF-I in hypoxia tolerance, we evaluated whether IGF-I stimulation can directly activate HIF- $1 \alpha$ in vitro. After serum starvation, we added IGF-I $(100 \mathrm{ng} / \mathrm{mL})$ to the cultured media for cortical neurons derived from newborn pups. With IGF-I treatment, neuronal viability was increased in low oxygen concentrations ( $5 \%$ and $1 \%)$. The most significant increase was seen at the lowest oxygen concentration (1\%), when neuronal survival decreased most (Fig. 5A). Among other potential mechanisms, IGF-I's survival effects may be mediated by activating HIF- $1 \alpha$. Results of EMSA demonstrated an increase in the HIF- $1 \alpha$ DNA binding activity in the nuclear extract from cortical neurons that were treated with IGF-I as well as with $\mathrm{CoCl}_{2}$, a transition metal that is known to increase HIF- $1 \alpha$ DNA binding activity (Fig. $5 B$ ).

Activation of HIF-1a after hypoxia preconditioning and hypoxia-ischemia. To see whether IGF-I may activate HIF-1 $\alpha$ in vivo, we used EMSA to examine the hypoxia-induced HIF- $1 \alpha$ activation in cortical tissues. EMSA was successfully used to measure HIF- $1 \alpha$ DNA binding activity in nuclear protein extracts derived from cortical tissues. Using a probe containing HIF- $1 \alpha$ consensus sequence (W18), there was an increase in HIF- $1 \alpha$ DNA binding activity in nuclear extracts after hypoxia, which was further increased with superimposed ischemia (Fig. 6A). There was no DNA binding activity detected when a mutant probe (M18) was used or when an antibody against HIF- $1 \alpha$ was included in the binding reaction (supershift). After hypoxia or hypoxia-ischemia, the increase in HIF- $1 \alpha$ DNA binding activity started around $5 \mathrm{~h}$ of recovery, reached maximum at approximately $24 \mathrm{~h}$, and started to decline by $72 \mathrm{~h}$ (Fig. 6, $B$ and $C$ ). With hypoxia preconditioning, HIF- $1 \alpha$ DNA binding activity was further increased in cortical tissues that received the second treatment of hypoxia or hypoxia-ischemia (Fig. $6 D$ ). To determine whether the increase in HIF- $1 \alpha$ DNA binding activity is associated with an increase in the expression of downstream target genes, we measured the mRNA levels of glucose transporter 1 by RT-PCR. As shown in Figure 7, hypoxia preconditioning resulted in an increase in the mRNA levels of this glucose transporter but not those of glucose transporter 3 (data not shown), which is not a target gene for HIF- $1 \alpha$.

\section{DISCUSSION}

In this study, we provided definitive evidence that hypoxiaischemia-induced apoptotic neuronal death can be alleviated by preexposing animals to sublethal doses of hypoxia. In three brain areas that are vulnerable to hypoxic-ischemic injury,

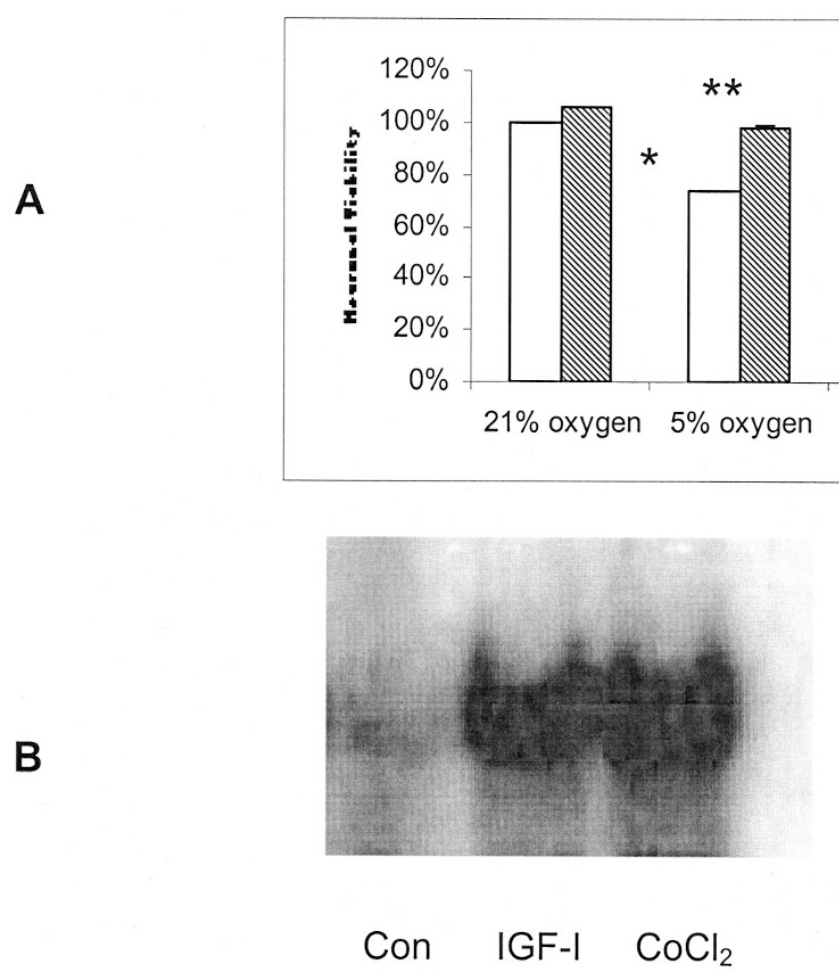

Figure 5. IGF-I increased HIF- $1 \alpha$ DNA binding activity and neuronal survival. Primary neuronal cultures were established from fresh cortical tissues derived from newborn rats. (A) After 16-h serum starvation, IGF-I was added into the culture media (Dulbecco's modified Eagle's medium) to a final concentration of $100 \mathrm{ng} / \mathrm{mL}$ and incubated for $8 \mathrm{~h}$. Neuronal viability was examined at $21 \%, 5 \%$, and $1 \%$ oxygen with or without IGF-I treatment for $24 \mathrm{~h}$ by MTT assay $(n=$ 2). Neuronal viability at $21 \%$ oxygen without IGF-I treatment was used as $100 \%$. At $5 \%$ and $1 \%$ oxygen, IGF-I promoted neuronal viability, which was otherwise substantially decreased. ANOVA: $* p<0.05$ among three groups; ${ }^{* *} p<0.05$ between groups with or without IGF-I treatment. $(B)$ Under the same culturing condition, HIF- $1 \alpha$ DNA binding activity was evaluated by EMSA. As a positive control, $\mathrm{CoCl}_{2}$ was added to a final concentration of $166 \mu \mathrm{M}$. Treatment with either IGF-I treatment or $\mathrm{CoCl}_{2}$ significantly increased HIF- $1 \alpha$ DNA binding activity in the nuclear protein extract. 


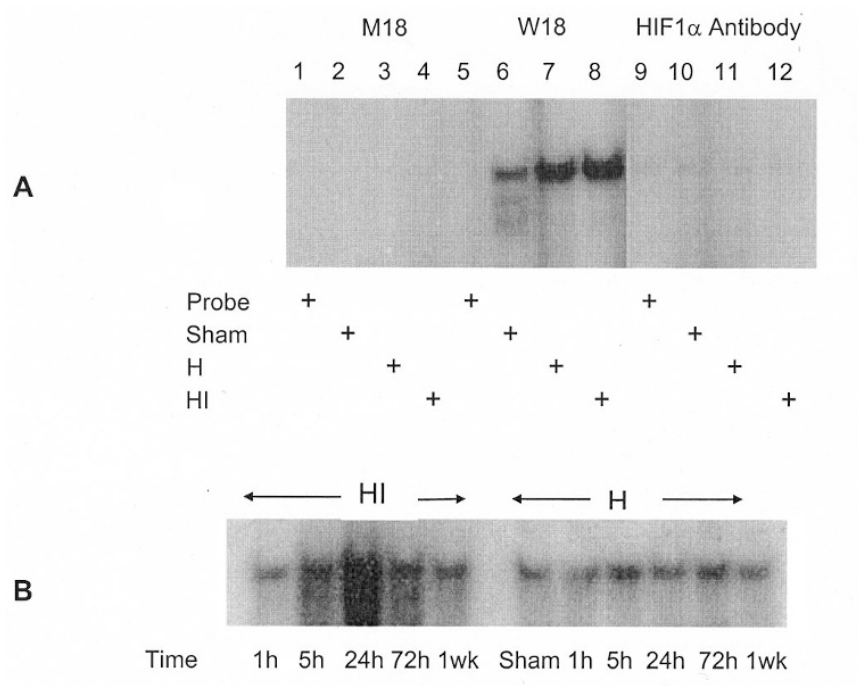

C

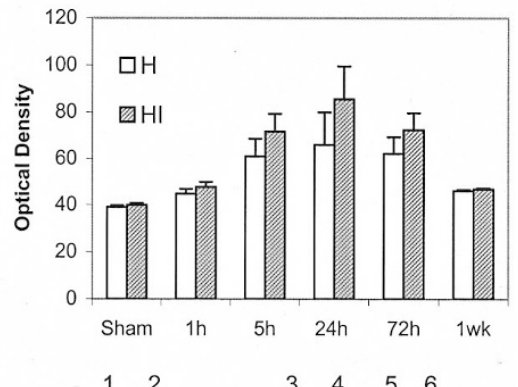

D

\section{Preconditioning Hypoxia}

Hypoxia-ischemia

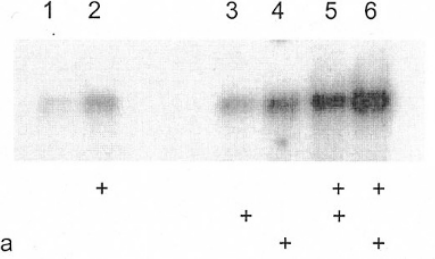

Figure 6. HIF- $1 \alpha$ DNA binding activity in rat cerebral cortex by EMSA. $(A)$ At $24 \mathrm{~h}(A$ and $D)$ of recovery, tissue samples were obtained from cortex that were supplied by middle cerebral artery. Whereas sham operation (lane 6) only resulted in low HIFi1 $\alpha$ DNA binding activity, hypoxia alone increased HIFil $\alpha$ DNA binding (lane 7), which was further increased by superimposed ischemia (lane 8 ). Only probe (W18) and no sample was added in the binding reaction in lane 5 . With the same four samples, no HIF- $1 \alpha$ DNA binding activity was detected when mutant probe (M18) was used (lanes 1-4), or when HIF-1 $\alpha$ antibody (1-200 dilution) was included in binding reaction (lanes 9-12). (B) Time course of HIF- $1 \alpha$ DNA binding activity after 150 min hypoxia alone $(H)$ or with superimposed ischemia $(H I)$. The mean \pm SD of densitometry analysis from two sets $(n=2)$ of samples are shown in $C$. $(D)$ HIF- $1 \alpha$ DNA binding activities were increased from sham-operated animals (lane 1) to a similar degree with preconditioning alone and hypoxia alone (lanes 2 and 3). Both superimposed ischemia (lane 4) and second hypoxia (lane 5) further increased HIF- $1 \alpha$ DNA binding activity. The highest HIF- $1 \alpha$ DNA binding activity was seen in cortical tissues that had hypoxia-ischemia with hypoxia preconditioning (lane 6).

hypoxia alone increased IGF-I mRNA levels, which was further increased with superimposed ischemia. In addition, after hypoxia-ischemia, there is a parallel increase in the DNA binding activity of HIF- $1 \alpha$, a transcription factor responsible for cellular adaptive responses. More interestingly, IGF-I directly increased HIF- $1 \alpha$ DNA binding activity and the survival of cultured primary neurons, which was consistent with IGFI's known survival activity. On the other hand, it is known that
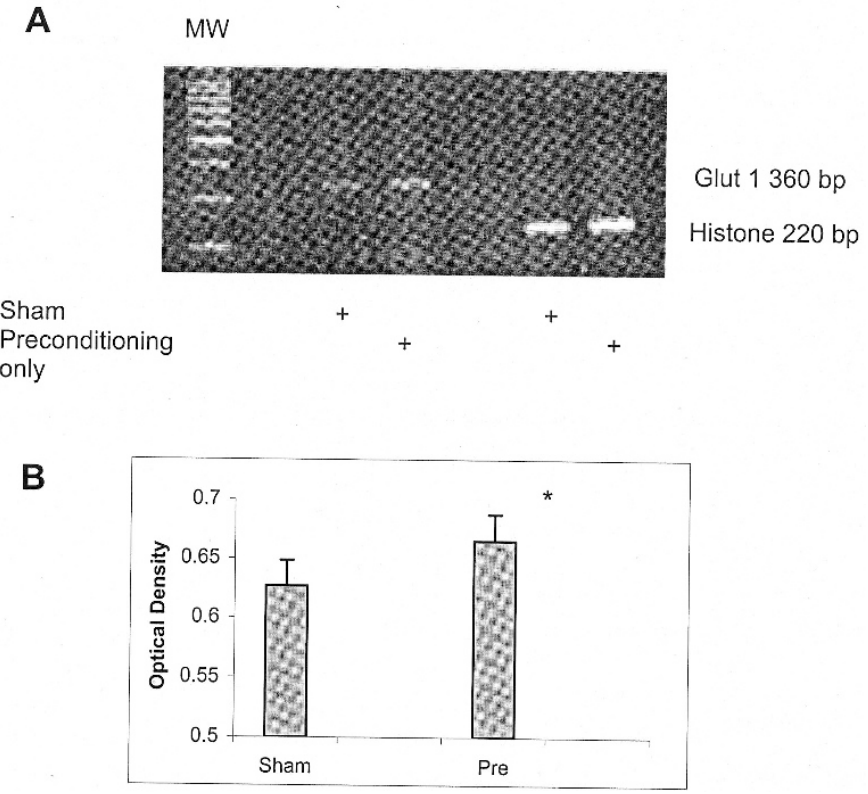

Figure 7. Glucose transporter 1 expression increased after hypoxia preconditioning. At $24 \mathrm{~h}$ of recovery, tissue samples were obtained from cortices that were supplied by middle cerebral artery. Using RT-PCR, the mRNA levels of glucose transportor1 (Glut1) was measured in the cortical tissues from animals that had sham operation or hypoxia preconditioning only $(n=4)$. The mRNA levels of histone were also measured in the same sample to control the sample loading $(A)$. The levels of Glut 1 mRNA were estimated by the OD on autographic film and expressed as mean $+\mathrm{SD}(B) .{ }^{*} p<0.05$ compared with mean Glut 1 mRNA levels after sham operation.

an increase in HIF- $1 \alpha$ activity will trigger metabolic adaptive responses that contribute to the subsequent neuroprotection or, namely, hypoxia tolerance. Therefore, our observations support the hypothesis that the endogenous adaptation mechanisms underlying hypoxic tolerance may include the induction of IGF-I expression, which, through activating the HIF-1 $\alpha$ signaling pathway, provides neuroprotection against hypoxiaischemia-induced neuronal injury.

Preconditioning and subsequent tolerance to a noxious insult is a normal cellular response essential for adapting to any shortages in the supply of metabolic substrates. This metabolic adaptation is important not only for cell survival but also for maintaining normal cellular functions $(23,35)$. Loss of response or over-adapting to metabolic stress will lead to cell death or malignant cell growth. Because of these broad implications, the mechanisms of preconditioning and tolerance have been intensely studied in recent years. One of the betterunderstood adaptation mechanisms is hypoxia preconditioning and tolerance. Exposing hippocampal slices (2) or cortical neurons (1) to a brief episode of hypoxia-induced hypoxia tolerance to subsequent hypoxia-ischemia. This hypoxia tolerance was also observed in vivo in a rodent model of hypoxia ischemia encephalopathy (29), which was used in the current study. Here, we report that this hypoxia tolerance likely involved the transcriptional activation of IGF-I. This is due to the fact that hypoxia alone increased IGF-I mRNA levels, which was further increased with subsequent hypoxia and more with superimposed ischemia. 
IGF-I is a pleiotropic anabolic factor essential for the survival of developing neurons. IGF-I itself is neuroprotective against hypoxic-ischemic injury in the same rodent model of hypoxia-ischemia. Neuronal IGF-I mRNA levels decreased almost immediately after the hypoxia-ischemia (18). As the hypoxia time increased, the decrease in IGF-I mRNA levels correlated with the increase in the number of apoptotic neurons (19). More importantly, infusion of exogenous IGF-I intraventricularly within $2 \mathrm{~h}$ of insult decreased neuronal damage in rats (14) and fetal sheep (20). To date, the mechanisms that mediate IGF-I's neuroprotection against hypoxia-ischemia have not been elucidated. Evidence from the current study supports the hypothesis that hypoxia-induced IGF-I transcriptional activation may contribute to IGF-I's neuroprotection against hypoxic-ischemic injury. As the oxygen level decreased from physiologic concentration, there was an increase in neuronal death both in vivo and in vitro. This hypoxiainduced neuronal death was partially prevented by including exogenous IGF-I in the culture media. Because IGF-I receptors are present on all brain cells (36), the hypoxia-induced expression of endogenous IGF-I may play an important role in the subsequent hypoxia tolerance.

After hypoxia, the mechanisms that induced IGF-I expression are not clear. Because GH passes the blood-brain barrier poorly (37), the expression of endogenous IGF-I in the CNS is regulated differently from that in the periphery. In the brain, IGF-I is expressed mainly by neurons, especially those in the relay centers of the somatosensory and cerebellar systems (34). GH produced in the brain may influence neuronal IGF-I production, as levels of GH receptor mRNA coordinate with those of IGF-I mRNA (38). In addition, neuronal IGF-I expression is influenced by developmental stage (34), nutrition status (39), glucocorticoid (40), and brain injury $(18,41)$. The upregulation of IGF-I expression by hypoxia alone has never been reported before and likely contributes to our understanding of both its regulation and function during normal brain development and abnormal situations.

The mechanisms that mediate IGF-I's neuroprotection against hypoxic-ischemic injury are not well delineated. IGF-I is better known for promoting neuronal survival via activating the PI3/Akt pathway $(42,43)$. Whether other pathways are involved in IGF-I's neuroprotective activity has not been thoroughly investigated. In our study, we saw a similar temporal change between IGF-I mRNA and HIF- $1 \alpha$ DNA binding activity. Like IGF-I, hypoxia alone increased HIF-1 $\alpha$ DNA binding activity, with the maximum increase at approximately $24 \mathrm{~h}$. When hypoxia was superimposed with ischemia, the same time course of HIF- $1 \alpha$ activation was also observed, but at higher levels. Because ischemia is primarily the depletion of glucose and oxygen, it is possible that the hypoxia component in the ischemia had an additive effect and, thereby, resulted in the higher level of HIF- $1 \alpha$ DNA binding activity. In all three brain regions, the number of apoptotic cells was inversely correlated with the levels of HIF- $1 \alpha$ DNA binding activity. HIF- $1 \alpha$ activation also triggered metabolic responses, as shown by the increase of the transcription of glucose transporter 1, a metabolic adaptive gene downstream of HIF- $1 \alpha$ activation. This hypoxia preconditioning-induced adaptive re- sponse likely contributed to a decrease in apoptotic neuronal death in three brain areas that are known to be sensitive to hypoxia-ischemia. The involvement of HIF-1 activation in hypoxia-induced ischemic tolerance was reported in the same hypoxia-ischemia model. In a previous study, increasing HIF- $1 \alpha$ protein levels after i.p. injection of $\mathrm{CoCl}_{2}$ provided neuroprotection to hypoxia ischemia, strongly supporting an important role for HIF-1 in hypoxia preconditioning-induced neuroprotection (29).

IGF-I is one of the factors that activate HIF- $1 \alpha$ DNA binding activity. In human Hep-G1 cells, IGF-I is capable of inducing the transcription of target genes through activating HIF $1 \alpha$ (30). Most recently, direct evidence of IGF-I-induced HIF- $1 \alpha$ activation was obtained in vivo (32). Intracerebroventricular or systemic IGF-I infusion induced HIF-1 $\alpha$ activation. Most interestingly, a selective IGF-I receptor antagonist abolished HIF- $1 \alpha$ accumulation, strongly suggesting that IGF-Iinduced HIF- $1 \alpha$ activation likely contributed to its neuroprotective activity. Our results added additional evidence for this hypothesis. Depending on the exposure to hypoxia preconditioning and subsequent hypoxia or hypoxia and ischemia, IGF-I mRNA levels increased coordinately with HIF- $1 \alpha$ DNA binding activity. In cultured primary neurons, IGF-I also increased HIF-1 $\alpha$ DNA binding activity as well as neuronal survival. This observation suggested that both HIF- $1 \alpha$ activation and IGF-I synthesis possibly contribute to hypoxia tolerance.

HIF-1 is known as a master transcription factor for regulating cellular metabolic adaptive responses according to the molecular oxygen concentration in our environment. Although HIF- $1 \alpha$ is a substrate of Akt (44), it is not clear whether IGF-I induced HIF- $1 \alpha$ activation occurs in vivo and contributes to its survival action. In fact, the regulation of metabolic adaptation fits well with IGF-I's biologic function as an anabolic growth factor in the CNS. Both IGF-I and IGF-I receptor share over $50 \%$ amino acid sequence homology with insulin (45), which accounts for the significant cross activities between IGF-I and insulin in regulating cell growth and metabolism. Because the survival of a cell, especially a cell having high metabolic demands such as a neuron, critically relies on its metabolic status, it is conceivable that a cell's metabolic adaptation ultimately contributes to its ability to survive. In this investigation, we demonstrated that IGF-I increased HIF- $1 \alpha$ DNA binding activity in the nuclear extract derived from cortical neurons in primary culture. In the meantime, IGF-I, when added into the culture media, increased neuronal viability under hypoxia culturing conditions. These results supported the hypothesis that IGF-I's neuroprotective effect against hypoxia-ischemia is partially mediated through activating the HIF1 metabolic adaptive pathway.

Overall, we used both in vivo and in vitro models to demonstrate that hypoxia preconditioning transactivated IGF-I expression and HIF- $1 \alpha$ DNA binding activity, which likely contributed to the subsequent neuroprotection against hypoxia ischemia. This HIF-1-induced metabolic response may play an integral part in IGF-I's ability to promote neuronal survival in metabolic stress. As an important neurotrophic factor for developing neurons, IGF-I likely plays a dominant role in the 
"nutrient-sensing" pathway that regulates neuronal survival as well as metabolic adaptation in nutrient deficiency.

\section{REFERENCES}

1. Ruscher K, Isaev N, Trendelenburg G, Weih M, Iurato L, Meisel A, Dirnagl U 1998 Induction of hypoxia inducible factor 1 by oxygen glucose deprivation is attenuated by hypoxic preconditioning in rat cultured neurons. Neurosci Lett 254:117-120

2. Perez-Pinzon MA, Mumford PL, Rosenthal M, Sick TJ 1996 Anoxic preconditioning in hippocampal slices: role of adenosine. Neuroscience 75:687-694

3. Gidday JM, Fitzgibbons JC, Shah AR, Park TS 1994 Neuroprotection from ischemic brain injury by hypoxic preconditioning in the neonatal rat. Neurosci Lett 168:221224

4. Vannucci RC, Towfighi J, Vannucci SJ 1998 Hypoxic preconditioning and hypoxicischemic brain damage in the immature rat: pathologic and metabolic correlates. J Neurochem 71:1215-1220

5. Miller BA, Perez RS, Shah AR, Gonzales ER, Park RS, Gidday JM 2001 Cerebra protection by hypoxic preconditioning in a murine model of focal ischemiareperfusion. Neuroreport 12:1663-1669

6. Bernaudin M, Nedelec A-S, Divoux D, MacKenzie ER, Petit E, Schumann-Bard P 2002 Normobaric hypoxia induces tolerance to focal permanent cerebral ischemia in association with an increased expression of hypoxia-inducible factor-1 and its target genes, erythropoietin and VEGF, in the adult brain. J Cereb Blood Flow Metab 22:393-403

7. Chen J, Simon R 1997 Ischemic tolerance in the brain. Neurology 48:306-311

8. Xu G-P, Dave KR, Vivero R, Schrnidt-Kastner R, Sick TJ, Perez-Pinzon MA 2002 Improvement in neuronal survival after ischemic preconditioning in hippocampal slice cultures. Brain Res 952:153-158

9. Kobayashi S, Harris VA, Welsh FA 1995 Spreading depression induces tolerance of cortical neurons to ischemia in rat brain. J Cereb Blood Flow Metab 15:721-727

10. Riepe MW, Ludolph AC 1997 Chemical preconditioning: a cytoprotective strategy. Mol Cell Biochem 174:249-254

11. Sizonenko SV, Sirimanne ES, Williams CE, Gluckman PD 2001 Neuroprotective effects of the N-terminal tripeptide of IGF-1, glycine-proline-glutamate, in the immature rat brain after hypoxic-ischemic injury. Brain Res 922:42-50

12. Gluckman PD, Guan J, Williams C, Scheepens A, Zhang R, Bennet L, Gunn A 1998 Asphyxial brain injury - the role of the IGF system. Mol Cell Endocrinol 140:95-99

13. Gluckman P, Klempt N, Guan J, Mallard C, Sirimanne E, Dragunow M, Klempt M, Singh K, Williams C, Nikolics K 1992 A role for IGF-1 in the rescue of CNS neurons following hypoxic-ischemic injury. Biochem Biophys Res Commun 182:593-599

14. Guan J, Williams C, Gunning M, Mallard C, Gluckman P 1993 The effects of IGF-1 treatment after hypoxic-ischemic brain injury in adult rats. J Cereb Blood Flow Metab 13:609-616

15. Guan J, Williams CE, Skinner SJ, Mallard EC, Gluckman PD 1996 The effects of insulin-like growth factor (IGF)-1, IGF-2, and des-IGF-1 on neuronal loss after hypoxic-ischemic brain injury in adult rats: evidence for a role for IGF binding proteins. Endocrinology 137:893-898

16. Guan J, Skinner SJ, Beilharz EJ, Hua KM, Hodgkinson S, Gluckman PD, Williams CE 1996 The movement of IGF-I into the brain parenchyma after hypoxic-ischaemic injury. Neuroreport 7:632-636

17. Guan J, Miller OT, Waugh KM, McCarthy DC, Gluckman PD 2001 Insulin-like growth factor-1 improves somatosensory function and reduces the extent of cortical infarction and ongoing neuronal loss after hypoxia-ischemia in rats. Neuroscience 105:299-306

18. Lee W-H, Wang G-M, Seaman LB, Vannucci SJ 1996 Coordinate IGF-I and IGFBP5 gene expression in perinatal rat brain after hypoxia-ischemia. J Cereb Blood Flow Metab 16:227-236

19. Clawson TF, Vannucci SJ, Wang G-M, Seaman LB, Yang X-L, Lee W-H 1999 Hypoxia-ischemia-induced apoptotic cell death correlates with IGF-I mRNA decrease in neonatal rat brain. Biol Signals Recept 8:281-293

20. Johnston BM, Mallard EC, Williams CE, Gluckman PD 1996 Insulin-like growth factor-1 is a potent neuronal rescue agent after hypoxic-ischemic injury in fetal lambs. J Clin Invest 97:300-308

21. Wang GL, Semenza GL 1995 Purification and characterization of hypoxia-inducible factor 1. J Biol Chem 270:1230-1237
22. Wang GL, Jiang BH, Rue EA, Semenza GL 1995 Hypoxia-inducible factor 1 is a basic-helix-loop-helix-PAS heterodimer regulated by cellular $\mathrm{O}_{2}$ tension. Proc Nat Acad Sci U S A 92:5510-5514

23. Semenza GL 1999 Regulation of mammalian $\mathrm{O}_{2}$ homeostasis by hypoxia-inducible factor 1. Annu Rev Cell Dev Biol 15:551-578

24. Ivan M, Kondo K, Yang H, Kim W, Valiando J, Ohh M, Salic A, Asara JM, Lane WS, Kaelin Jr SG 2001 HI Falpha targeted for VHL-mediated destruction by proline hydroxylation: implications for $\mathrm{O}_{2}$ sensing. Science 292:464-472

25. Lando D, Peet DJ, Whelan DA, Corman JJ, Whitelaw ML 2002 Asparagine hydroxylation of the HIF transactivation domain: a hypoxic switch. Science 295:858-861

26. Scalceda S, Caro J 1997 Hypoxia-inducible factor 1alpha (HIF-1alpha) protein is rapidly degraded by the ubiquitin-proteasome system under normoxic conditions. Its stabilization by hypoxia depends on redo-induced changes. J Biol Chem 272:2264222647

27. Huang LE, Gu J, Schau M, Bunn HF 1998 Regulation of hypoxia-inducible factor lalpha is mediated by an $\mathrm{O}_{2}$-dependent degradation domain via the ubiquitinproteasome pathway. Proc Natl Acad Sci U S A 95:7987-7992

28. Jiang BH, Semenza GL, Bauer C, Marti HH 1996 Hypoxia-inducible factor 1 levels vary exponentially over a physiologically relevant range of $\mathrm{O}_{2}$ tension. Am J Physiol 271:C1172-C1180

29. Bergeron M, Gidday JM, Yu AY, Semenza GL, Ferriero DM, Sharp FR 2000 Role of hypoxia-inducible factor-1 in hypoxia-induced ischemic tolerance in neonatal rat brain. Ann Neurol 48:285-296

30. Zelzer E, Levy Y, Kahana C, Shilo BZ, Rubinstein M, Cohen B 1998 Insulin induces transcription of target genes through the hypoxia-inducible factor HIF-1alpha/ARNT. EMBO J 17:5085-5094

31. Tazuke SI, Mazure NM, Sugawara J, Carland G, Faessen GH, Suen LF, Irwin JC, Powell DR, Giaccia AJ, Giudice LC 1998 Hypoxia stimulates insulin-like growth factor binding protein 1 (IGFBP-1) gene expression in HepG2 cells: a possible model for IGFBP-1 expression in fetal hypoxia. Proc Natl Acad Sci U S A 95:10188-10193

32. Chavez JC, LaManna JC 2002 Activation of hypoxia-inducible factor-1 in the rat cerebral cortex after transient global ischemia: potential role of insulin-like growth factor-1. J Neurosci 22:8922-893

33. Rice JE, III, Vannucci RC, Brierley JB 1981 The influence of immaturity on hypoxic-ischemic brain damage in the rat. Ann Neurol 9:131-141

34. Bondy CA 1991 Transient IGF-I gene expression during the maturation of functionally related central projection neurons. J Neurosci 11:3442-3455

35. Wenger RH 2000 Mammalian oxygen sensing, signalling and gene regulation. J Exp Biol 203:1253-1263

36. Bondy C, Werner H, Roberts Jr CT, LeRoith D 1992 Cellular pattern of typeinsulin-like growth factor receptor gene expression during maturation of the rat brain: comparison with insulin-like growth factors I and II. Neuroscience 46:909-923

37. Coculescu M 1999 Blood-brain barrier for human growth hormone and insulin-like growth factor-I. J Pediatr Endocrinol Metab 12:113-124

38. Shoba L, An MR, Frank SJ, Lowe Jr WL 1999 Developmental regulation of insulin-like growth factor-I and growth hormone receptor gene expression. Mol Cell Endocrinol 152:125-136

39. Calikoglu A, Karayal A, D'Ercole AJ 2001 Nutritional regulation of IGF-I expression during brain development in mice. Pediatr Res 49:197-202

40. Ye P, Umayahara Y, Ritter D, Bunting T, Auman H, Rotwein P, D’Ercole AJ 1997 Regulation of insulin-like growth factor I (IGF-I) gene expression in brain of transgenic mice expressing an IGF-I-luciferase fusion gene. Endocrinology 138:5466-5475

41. Lee W-H, Clemens JA, Bondy CA 1992 Insulin-like growth factors in the response to cerebral ischemia. Mol Cell Neurosci 3:36-43

42. Zhong J, Deng J, Ghetti B, Lee W-H 2002 Inhibition of insulin-like growth factor activity contributes to the premature apoptosis of cerebellar granule neuron in weaver mutant mice: in vitro analysis. J Neurosci Res 70:36-45

43. Dudek H, Datta SR, Franke TF, Birnbaum MJ, Yao R, Cooper GM, Segal RA, Kaplan DR, Greenberg ME 1997 Regulation of neuronal survival by the serine-threonine protein kinase Akt. Science 275:661-664

44. Datta SR, Brunet A, Greenberg ME 1999 Cellular survival: a play in three Akts. Genes Dev 13:2905-2927

45. Daughaday WH, Rotwein P 1989 Insulin-like growth factors I and II. Peptide, messenger ribonucleic acid and gene structures, serum, and tissue concentrations. Endocr Rev 10:68-91 